\section{Medical Rehabilitation}

A BookLex published by the Ministry of Health entitled "The Road Back to Health" (H.M. Stationery Office, 1947. 6d. ; 7d. including postage) describes the process called rehabilitation by which injured or sick people are cared for, right from the beginning, with the object of returning them eventually to as full a measure of health and activity as is possible. The booklet tells its story well, and readers of it will be surprised by the degree of useful activity and happiness which can nowadays be conferred upon people whose injuries or illnesses used to cripple them and hasten the end of life. Excellent photographs show patients undergoing this continuous and beneficial treatment, facilities for which are available now at more than three hundred hospitals in England and Wales. Nobody can look at these or read the text of this booklet without commending both the present work and the plans for its future which are outlined in a concluding chapter. The booklet is intended chiefly for hospital authorities, doctors, employers, welfare workers and others closely associated with the care of the sick and injured; but the co-operation of everyone in this work is required, and especially that of the patient, so that the more the general public learn about it the better. The loss of a lung or an apparently irremediable injury of a vital limb or joint need no longer condemn either man, woman or child to be a life-long cripple or dependent on others. Modern medicine and surgery have given us in recent years many spectacular benefits of mankind and most of them have been well and extensively interpreted to the public. Rehabilitation is not so well known or understood. It depends upon the patient and highly skilled co-operation of doctors, nurses and others, and cannot succeed without the active help of the sick or injured person. It is a service to mankind which must be classed as one of the greatest achievements of modern times.

\section{Seismology at Oxford}

Mrss E. F. Bellamy, well known for her seismological work, has retired from her post as assistant at the Oxford University Observatory. It is hoped that she will enjoy a long and congenial retirement. The connexion between the Oxford University Observatory and seismology which was effected by the late Prof. H. H. Turner, enhanced by Prof. H. H. Plaskett and cemented by Miss Bellamy and others is being severed. The centre, where the calculations are done before the publication of the International Seismological Summary, has already been moved, by courtesy of the Director of the Meteorological Office, Air Ministry, to Kew Observatory, Richmond, Surrey.

The two Milne-Shaw seismographs belonging to the British Association Seismological Committee have been moved to Charles Darwin's old home at Down House, Downe, Kent (latitude $51^{\circ} 19^{\prime} \mathrm{N}$., longitude $0^{\circ} 4^{\prime}$ E.) and put in charge of Dr. O. J.R. Howarth, who, until recently, was secretary of the British Association for the Advancement of Science. Dr. Howarth is setting up the instruments on pillars in the basement of the house and hopes to bring the seismographs into use shortly. Down House is situated on a clay-with-flints cap over the chalk of the North Downs.

\section{Weather Control Predicted}

Sky and Telescope for April contains a short note on this subject in connexion with an address by Dr.
V. K. Zworykin before the U.S. Institute of Aeronautical Sciences. He pointed out that new electronic calculators will yield rapid results regarding weather forecasts, and it may be possible to alter the weather by the release of a relatively small amount of energy which will have a 'trigger' effect. One method suggested is to spread a large amount of oil on water and ignite it; the resulting updraught would then change the motions of the higher-level air masses. Another method would utilize solar radiation at 'weather control areas', these consisting of large absorbing areas blackened by carbon deposits. These could be easily changed when desirable into highly reflecting areas by the formation of artificial fogs.

\section{Announcements}

Mr. N. B. Kinnear, the well-known ornithologist, keeper of zoology in the British Museum (Natural History) since 1945, has been appointed director of the Museum in succession to Sir Clive Forster-Cooper, who retires on October 1 .

National Research Corporation, Cambridge, Mass., in eo-operation with the Division of Industrial and Engineering Chemistry, American Chemical Society, is arranging a symposium on "High Vacuum" to be held in Cambridge, Massachusetts, during October 30 and 31. Attendance will be restricted to technical and scientific personnel concerned with industrial applications of high vacuum. A report and the papers will be published in due courso in Industrial and Engineering Chemistry. The secretary of the symposium is Mr. Stanley Heck, National Research Corporation, Cambridge 42, Massachusetts.

Publication No. 15 of Messrs. C. A. Parsons and Co., Ltd., Heaton Works, Newcastle-upon-Tyne 6 , is an illustrated four-page pamphlet describing the Sir Howard Grubb, Parsons and Co.'s infra-red gas analyser, the operation of which depends on the fact that most of the common gases have strong absorption bands in the infra-red region of the spectrum. Each instrument is complete with one detecting unit filled with a particular gas, but additional units filled with other gases can be supplied and the replacement made by tho user in a minute or two. Gases which can be estimated with the apparatus include carbon monoxide, carbon dioxide, methane, ethylene and other hydrocarbon gases.

We regret to announce the following deaths:

Dr. John Parkinson, known for his geological work in various parts of Africa, Trinidad, India and Burma, on July 19, aged seventy-five.

Mr. R. I. Pocock, F.R.S., superintendent of the Zoological Society's Gardens, London, during 1904-23, on August 9, aged eighty-four.

Sir William Thomson, professor of mathematics in Victoria College, Stellenbosch, during 1883-95, principal of the University of the Witwatersrand, Johannesburg, during 1924-28, on August 6, aged ninety.

Prof. W. W. Watts, F.R.S., emeritus professor of geology in the Imperial College of Science and Technology, Jondon, on July 30, aged eightyseven. 